\author{
V.I. Kyrychenko ${ }^{1}$, V.V. Kyrychenko², V.S. Ribun ${ }^{3}$, M.B. Skladaniuk ${ }^{3}$
}

\title{
Alternative Fuels from Vegetable Oils: Innovative Methods and Technologies of Production and Usage
}

\author{
${ }^{1}$ Khmelnytsky National University, Khmelnytskyi, Ukraine, vikirich@ukr.net \\ ${ }^{2}$ Pacell LLC, Kyiv, Ukraine, Kyrychenkovk@gmail.com \\ ${ }^{3}$ Vasyl Stefanyk Precarpathian National University, Ivano-Frankivsk, Ukraine, ribun.vika@ gmail.com. \\ skladanyuk16@gmail.com
}

Traditional methods of biofuel production using vegetable oils and aliphatic alcohols (alcoholysis) have a number of disadvantages. A new method of transesterification of vegetable oils with alkyl acetates (esterolysis) is proposed. Esterolysis solves the problem of alcohol content in biofuels. It is not necessary to remove alkyl acetates from biofuels because they act as promoters of diesel fuel combustion. A method of improving both technology of alcoholysis and esterolysis by modifying the temperature range is proposed. Chemical and technological bases of two-stage process of vegetable oil transesterification are developed. In the first stage, the oils are treated with glycerol (glycerolysis) in order to convert tri-acyl-glyceros of oil into mono-acyl-glycerols. The second stage is alcoholysis of mono-acyl-glycerols with ethanol (ethanolysis) or esterolysis of mono-acylglycerols with ethyl acetate. The temperature range of the transesterification process is improved using heattransfer solvents. Comparison of material balances of technologies of one- and two-stage ways of ethanolysis and esterolysis showed a significant increase in the selectivity of the process, yield and quality of biofuels. Analysis of the obtained biofuels and mixtures, which contain $20 \%$ of biofuels and $80 \%$ of diesel fuel showed the best physical, chemical and operational characteristics. Therefore, the blended fuels are promising area of biofuel technology. fuel.

Key words: rapeseed oil, ethanolysis, esterolysis, tri-acyl-glycerol, mono-acyl glycerol, biofuel, blended

Received 10 September 2020; Accepted 15 September 2020.

\section{Introduction}

One of the ways to solve the current problem of energy and resource support of the state economy, as well as environmental safety is to develop new, effective methods and technologies of renewable raw material conwersion into products with high biodegradability, which can be used as components for blended fuels and lubricants. Using vegetable oils makes possible to produce basic biocomponents for fuels and lubricants, in particular: a) biofuels for blended diesel or jet fuels; b) basic components for the production of composite lubricants (biooils, oil dispersion media, technical bioliquids, lubricants and coolants for metal treatment processes) $[1,2,5]$. It is known that pure vegetable oils cannot be used as fuel due to the significant difference in the properties of oils and traditional motor fuels. For example, oils have high values of molecular mass $(\mathrm{M}=890)$, density, viscosity, crystallization, boiling and flash point $[1,2,9,11]$. That is why the processing of base oils into fuel biocomponents is considered an urgent problem in the development of effective methods for the conversion of oil molecules into products whose properties are related to the properties of mineral fuels. 
The currently known methods of processing rapeseed oil into biofuels are based on chemical reactions of transesterification of tri-acyl-glycerol molecules with alcohols (alcoholysis) or acetates of those alcohols (esterolysis). The aim of such reactions is to replace the glycerol residuemin oilmolecule with simpler alkoxyl group -OAlk, for example, $-\mathrm{OCH}_{3}$ or $-\mathrm{OC}_{2} \mathrm{H}_{5}$ to form a methyl or ethyl ester of higher fatty acids having general formula R-C(O)-OAlk [1, 3, 4, 5 ].

Today, the most technologically developed and implemented in production are the processes based on the transesterification of oils with methanol and ethanol. Biofuel production by traditional methods has significant disadvantages of their technologies, which are mainly caused by two factors: a) the factor of reversibility of heterogeneous reactions under limited temperature (75 $80{ }^{\circ} \mathrm{C}$ ); b) a factor of specific tri-acyl-glycerol structure of vegetable oil molecules with three ester groups, which have different energy stability $[2,5]$.

In addition, the practice of diesel engine operation on biofuel based on higher fatty acid methyl esters shows that use of biofuel as a motor fuel has a negative impact on both engine performance and operation of its individual components $[1,4,9]$. That is why blended fuels containing $10-20 \%$ of biofuel and $80-90 \%$ mineral diesel fuel are considered to be more more desirable to use $[1,4,8,9]$.

\section{Experimental}

The use of the first proposed method of esterolysis of oils with ethyl acetate can only partially eliminate the adverse factors of alcoholysis. In particular, the following are achieved: a) the reaction medium is homogeneous from the beginning to the end of the process; b) reduction of excess ethyl acetate in product and the ability to leave it in the biofuel as a combustion promoter; c) absence of hydrophilic $\mathrm{OH}$-containing byproducts (harmful to fuels). However, esterolysis has other disadvantages similar to alcoholysis.

Comparison of chemical and technological bases of both one-stage methods of transesterification shows their similarity in low values of such leading indicators of the effectiveness of their technologies as selectivity, yield and quality of biofuels. It is important to take into account the influence of physical and chemical characteristics of raw materials and products on ethanolysis and esterolysis:

a) rapeseed oil $[\mathrm{RC}(\mathrm{O})-]_{3}-\mathrm{O}_{3} \mathrm{C}_{3} \mathrm{H}_{5}, \quad \mathrm{M} \approx 886$, $\mathrm{d}_{4}^{20}=915 \mathrm{~kg} / \mathrm{m}^{3}, v_{40}{ }^{\circ} \mathrm{C}=34-37 \mathrm{~mm}^{2} / \mathrm{s}$, does not dissolve alcohols, but dissolves ethyl acetate, mineral and biofuels, benzene well;

b) the main product - biofuels, ethyl esters of higher fatty acids $\mathrm{R}-\mathrm{C}(\mathrm{O})-\mathrm{O} \mathrm{C}_{2} \mathrm{H}_{5}, \mathrm{M} \approx 310, \mathrm{~d}_{4}^{20}=865 \mathrm{~kg} / \mathrm{m}^{3}$, $\mathrm{t}_{\text {boiling }}=205^{\circ} \mathrm{C}, \mathrm{t}_{\text {freezing }}=-15 \ldots-25^{\circ} \mathrm{C}$;

c) by-products that are a mixture of oil esters, glycerol derivatives, and glycerol $\mathrm{M}_{\mathrm{av}} \approx 480$ - 550 .

Material calculations were performed taking into account the following conditions: a) $1 \mathrm{~kg}$ of rapeseed oil was consumed; b) conversion of raw materials and yield of the final product both are equal to $80 \%$; c) the reaction mass has been heated with constant stirring

Table 1

Comparison of traditional methods of alcoholysis and esterolysis

Alcoholysis of rapeseed oil with ethanol $\mathrm{C}_{2} \mathrm{H}_{5} \mathrm{OH}$ $\left(\mathrm{M}=46 \mathrm{~g} / \mathrm{mol}, d_{4}^{20}=789 \mathrm{\kappa g} / \mathrm{m}^{3}, \mathrm{t}_{\text {boiling }}=78^{\circ} \mathrm{C}\right.$, $\mathrm{P}_{\text {saturated vapor pressure }}=9,7 \kappa \mathrm{Pa}, \mathrm{V}_{1}=0,058 \mathrm{l}$ )
Esterolysis of rapeseed oil with ethyl-acetate $\mathrm{CH}_{3} \mathrm{C}(\mathrm{O}) \mathrm{C}_{2} \mathrm{H}_{5}$

$\left(\mathrm{M}=88 \mathrm{~g} / \mathrm{mol}, d_{4}^{20}=900 \mathrm{\kappa g} / \mathrm{m}^{3}, \mathrm{t}_{\text {boiling }}=77^{\circ} \mathrm{C}, \mathrm{P}_{\text {saturated }}\right.$

Alcoholysis equation

$3[\mathrm{RC}(\mathrm{O})-]_{3}-\mathrm{O}_{3} \mathrm{C}_{3} \mathrm{H}_{5}+6 \mathrm{C}_{2} \mathrm{H}_{5} \mathrm{OH} \leftrightarrow$

$\leftrightarrow 6 \mathrm{R}-\mathrm{C}(\mathrm{O})-\mathrm{O} \mathrm{C}_{2} \mathrm{H}_{5}$ (main Product) +

$\left[\mathrm{RC}(\mathrm{O})-\mathrm{CH}_{2}\right]_{2}-\mathrm{CH}-\mathrm{OH}$ (BY-product 1, M = 620) +

$\mathrm{RC}(\mathrm{O})-\mathrm{CH}_{2}-\mathrm{C}_{2} \mathrm{H}_{3}-(\mathrm{OH})$ (BY-PROduct 2, $\mathrm{M}=356$ ) + $\mathrm{C}_{3} \mathrm{H}_{5}(\mathrm{OH})_{3}$ (GLYCEROL, $\mathrm{M}=92$ ) vapor pressure $=13,3 \mathrm{\kappa Pa}, \mathrm{V}_{1}=0,098 \mathrm{l}$ )

\begin{tabular}{|c|}
\hline Esterolysis equation \\
\hline 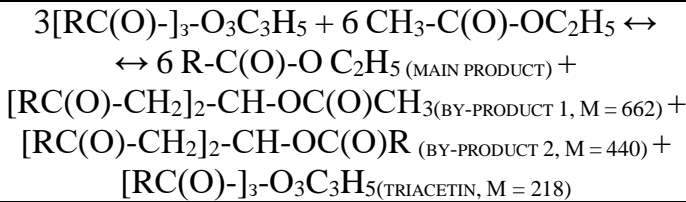 \\
\hline
\end{tabular}

Table 2

Material calculations of ethanolysis and esterolysis

\begin{tabular}{|c|c|}
\hline \multicolumn{2}{|c|}{ Consumption of non-oil raw material } \\
\hline $\begin{array}{c}\text { Ethanol ( } 200 \% \text { excess }) \\
\mathrm{V}_{\mathrm{et}}=0,3931, \mathrm{~m}=0,310 \mathrm{\kappa g}\end{array}$ & $\begin{array}{l}\text { Ethyl-acetate }(100 \% \text { excess }) \text { : } \\
\mathrm{V}_{\text {et. ac. }}=0,4121, \mathrm{~m}=0,397 \mathrm{\kappa g}\end{array}$ \\
\hline \multicolumn{2}{|c|}{ Excess of non-oil raw material in the mass of products } \\
\hline $\mathrm{V}_{\mathrm{et}}=0,288 \mathrm{l}, \mathrm{m}=0,235 \mathrm{\kappa g}$ & $\mathrm{V}_{\text {et. ac. }}=0,2641, \mathrm{~m}=0,258 \mathrm{\kappa g}$ \\
\hline \multicolumn{2}{|c|}{ The excess of rapeseed oil in the mass of products $\mathrm{m}_{\text {rapseed oil }}=0,200 \mathrm{\kappa g}$} \\
\hline \multicolumn{2}{|c|}{$\begin{array}{l}\text { The mas of products: } \\
\text { a) the main product - biofuel (bio.f.) }\end{array}$} \\
\hline $\mathrm{m}_{\text {bio.f. }}=0,560 \mathrm{\kappa g}(65,8 \%)$ & $\mathrm{m}_{\text {bio.f. }}=0,560 \mathrm{\kappa g}(63 \%)$ \\
\hline \multicolumn{2}{|c|}{ б) by-products (by-pr. 1, 2) } \\
\hline $\mathrm{m}_{\text {by-pr. }}=0,294 \mathrm{\kappa g}(34,4 \%)$ & $\mathrm{m}_{\text {by-pr }}=0,332$ кг $(37 \%)$ \\
\hline $\mathrm{V}_{\text {glycerol }}=0,0221, \mathrm{~m}_{\text {glycerol }}=0,028 \mathrm{\kappa g}$ & $\mathrm{V}_{\text {triacetin }}=0,0571, \mathrm{~m}_{\text {triacetin }}=0,066 \mathrm{\kappa g}$ \\
\hline
\end{tabular}


(heterogeneous in the case of ethanolysis and homogeneous in the case of esterolysis) at a temperature of $80-85^{\circ} \mathrm{C}$ for $8-10$ hours.

The properties of by-products, which are formed as a result of each method reactions are quite different from the properties of biofuels, as they are oil products. Both processes are influenced by the following technological factors:

1) reversibility of chemical reactions $(\leftrightarrow)$, which requires a shift of chemical equilibrium towards the formation of biofuels using a significant excess of nonoil reagents or changing the process temperature;

2) low selectivity and yield of biofuels (63-68\%) and bad quality of the obtained product, due to the formation of a mixture of by-products, which are soluble in biofuels well;

3) separation of pure biofuels, which may remain unwanted by-products in the range of $2.0-4.0 \%$ is timeconsuming and costly;

4) phase state of the reaction media: heterogeneity and as a consequence turbulent mixing using significant ethanol excess $(250-400 \%)$ and homogeneity and respectively laminar mixing using less excess ethyl acetate $(50-150 \%)$ than ethanol excess.

\subsection{Features of separation technology of products}

In the separation process of products into components, there are four stages:

- distillation $\left(85-95^{\circ} \mathrm{C}\right)$ of excess residual reagents: ethanol $\mathrm{V}_{\text {et }}=0.288 \mathrm{l}$ or ethyl acetate $\mathrm{V}_{\text {et.ac }}=0.155 \mathrm{l}$;

- distillation of by-products under vacuum: after ethanolysis of 0.0221 of glycerol, and after esterolysis - 0.0571 of triacetin;

- biofuels with mass $\mathrm{m}=0.560 \mathrm{~kg}$ and volume $\mathrm{V}=$ $0.640-0.6471$ are distilled off under vacuum;

- in residue there is a technical oil product (t. oil), which consists of by-products and rapeseed oil. For ethanolysis $\mathrm{m}_{\mathrm{t} . \mathrm{oil} .}=0.494 \mathrm{~kg}$, and for esterolysis $\mathrm{m}_{\mathrm{t} . \mathrm{ol}}=$ $0.532 \mathrm{~kg}$.

Since the considered one-stage methods of processing rapeseed oil into biofuel (traditional ethanolysis and new - esterolysis) are similar in main indicators, namely, low level of selectivity for biofuels and limited heating range $\left(\sim 80^{\circ} \mathrm{C}\right)$, both can be estimated only on the basis material balance of ethanolysis (Table 3).

Table 3

Material balance of the technological process of obtaining biofuel using the traditional method of rapeseed oil ethanolysis

\begin{tabular}{|c|c|c|c|c|c|c|c|}
\hline Raw materials & $\begin{array}{c}\text { Mass, } \\
\text { кg }\end{array}$ & $\begin{array}{c}\text { Volume, } \\
1\end{array}$ & $\begin{array}{c}\text { The } \\
\text { amount of } \\
\text { substance, } \\
\text { mol }\end{array}$ & Products & $\begin{array}{l}\text { Mass, } \\
\text { кg }\end{array}$ & $\begin{array}{c}\text { The } \\
\text { amount of } \\
\text { substance, } \\
\text { mol }\end{array}$ & $\begin{array}{l}\text { Yield, } \\
\text { Y, \% }\end{array}$ \\
\hline Rapeseed oil & 1,000 & 1,093 & 1,13 & \multirow{2}{*}{$\begin{array}{l}\text { Biofuel: } \\
\text { theoretical } \\
\text { actual }\end{array}$} & \multirow[b]{2}{*}{$\begin{array}{l}0,700 \\
0,560\end{array}$} & \multirow[b]{2}{*}{$\begin{array}{l}2,26 \\
1,81\end{array}$} & \multirow[b]{2}{*}{$\begin{array}{c}100 \\
80\end{array}$} \\
\hline $\begin{array}{c}\text { Ethanol: } \\
\text { from reaction } \\
\text { equation } \\
\text { under } 200 \% \text { excess }\end{array}$ & $\begin{array}{l}0,104 \\
0,312\end{array}$ & $0,10.390,331$ & $\begin{array}{l}2,26 \\
6,78\end{array}$ & & & & \\
\hline \multirow[t]{2}{*}{$\begin{array}{c}\text { Catalyst } \\
\mathrm{C}_{2} \mathrm{H}_{5} \mathrm{ONa} 1,5 \% \text { of } \\
\text { mass of reaction }\end{array}$} & \multirow[t]{2}{*}{0,020} & \multirow[t]{2}{*}{-} & \multirow[t]{2}{*}{0,34} & $\begin{array}{l}\text { By-products: } \\
\text { mono - i } \\
\text { diacylglycerols }\end{array}$ & $\begin{array}{l}0,294 \\
0,028 \\
\end{array}$ & $\begin{array}{l}0,60 \\
0,30 \\
\end{array}$ & - \\
\hline & & & & $\begin{array}{l}\text { Raw material: } \\
\text { ethanol } \\
\text { rapeseed oil } \\
\text { catalyst }\end{array}$ & $\begin{array}{l}0,235 \\
0,200 \\
0,020\end{array}$ & $\begin{array}{l}5,11 \\
0,23 \\
0,34\end{array}$ & - \\
\hline Total & 1,332 & 1,486 & 8,25 & Total & 1,337 & 8,35 & \\
\hline
\end{tabular}

Table 4

Material calculations of two-stage technology of ethanolysis and esterolysis

\begin{tabular}{|c|c|}
\hline \multicolumn{2}{|c|}{ Consumption of non-oil raw material under the condition of $92 \%$ conversion and $25 \%$ excess. } \\
\hline Ethanol $\mathrm{V}_{\mathrm{et}}=0,2191$ & Ethyl-acetate $\mathrm{V}_{\text {ey. ac. }}=0,2781$ \\
\hline \multicolumn{2}{|c|}{ Excess of non-oil raw material in the mass of products } \\
\hline $\begin{array}{c}\mathrm{V}_{\mathrm{et}}=0,058 \mathrm{l} \\
\text { Rapeseed oil } \mathrm{m}_{\text {rapeseed oil }}=0,071 \mathrm{\kappa g} \\
\text { mono-acyl-glycerol m } \mathrm{m}_{\mathrm{m}-\mathrm{ac}-\mathrm{gl}}=0,080 \mathrm{\kappa g}\end{array}$ & $\begin{array}{c}\mathrm{V}_{\text {et. ac. }}=0,264 \mathrm{l} \\
\text { Rapeseed oil } \mathrm{m}_{\text {rapeseed oil }}=0,071 \mathrm{\kappa g} \\
\text { mono-acyl-glycerol } \mathrm{m}_{\mathrm{m}-\mathrm{ac}-\mathrm{gl}}=0,080 \mathrm{\kappa} \Gamma\end{array}$ \\
\hline \multicolumn{2}{|c|}{$\begin{array}{l}\text { The mas of products: } \\
\text { a) the main product - biofuel (bio.f.) if yield of bio.f. }=92 \%\end{array}$} \\
\hline $\mathrm{m}_{\text {bio.f. }}=0,862 \kappa г, \mathrm{~V}_{\text {bio.f. }}=0,9971$ & $\mathrm{~m}_{\text {bio.f. }}=0,862 \kappa \Gamma, \mathrm{V}_{\text {bio.f. }}=0,9971$ \\
\hline \multicolumn{2}{|c|}{ б) water-soluble by-productsc } \\
\hline $\mathrm{V}_{\text {glycerol }}=0,0681, \mathrm{~m}_{\text {glycerol }}=0,085 \mathrm{\kappa g}$ & $\mathrm{V}_{\text {monoacetin }}=0,3091, \mathrm{~m}_{\text {monoacetin }}=0,373 \mathrm{\kappa g}$ \\
\hline
\end{tabular}


Comparison of chemical equations of ethanolysis and esterolysis shows that the esterolysis with ethyl acetate has certain advantages over ethanolysis, namely, homogeneous medium, hydrophilic $\mathrm{OH}$-containing byproducts are absent in the product mass, usage of ethyl or methyl acetate as a promoter additive to blended fuels. However, the main unfavorable factors, namely the low level of selectivity of reactions to biofuels, limited temperature range are unresolved. In order to increase the efficiency of ethanolysis and esterolysis technologies significantly, it was necessary to develop a method of their chemical modification, which would eliminate the whole set of adverse factors.

\subsection{Two-stage method of rapeseed oil transesterification}

An innovative approach to the development of such a method should eliminate the main reason for the low selectivity of these technologies, namely, to modify the triacyl-glycerol structure of oil molecules, which determines the multidirectionality of transesterification reactions. At the same time there are three ways of interaction between 1,2,3-ester parts of glycerols of oils and non-oil reagents (alcohols, esters):

- interaction with three fragments, which leads to the formation of biofuel $\mathrm{RC}(\mathrm{O})-\mathrm{OC}_{2} \mathrm{H}_{5}$;

- transesterification between only two parts $(1,3-$ or 1,2-) of glycerols and non-oil reagents to form monoacyl-glycerols $\mathrm{RC}(\mathrm{O})-\mathrm{OCH}_{2}-\mathrm{C}_{2} \mathrm{H}_{3}(\mathrm{OH})_{2}, \mathrm{M}-356$;

- interaction between only one part of glycerols and non-oil reagents to form diacyl-glycerols [RC(O)- $\left.\mathrm{OCH}_{2}\right]-\mathrm{CH}-\mathrm{OH}, \mathrm{M}$ 620. This polydirectional interaction leads to the accumulation of up to $30-35 \%$ of by-products of oil structure and hydrophilic byproducts harmful to motor fuels in general $[2,10,11]$.

It is obvious that for transesterification of vegetable oils and obtaining biodiesel using these methods, it is first necessary to transform tri-acyl-glycerol oil molecules $(\mathrm{M}=886)$ into mono-acyl-glycerol molecules $\mathrm{RC}(\mathrm{O})-\mathrm{OCH}_{2}-\mathrm{C}_{2} \mathrm{H}_{3}(\mathrm{OH})_{2}$. This transformation can be implemented by a rather simple technologically and efficient method of glycerolysis of oils, that is alcoholysis with glycerol in a molar ratio of 1: $2(\sim 2.2)$. Moreover, glycerolysis is considered as a general first stage of a two-stage method of vegetable oil treatment. The second stage is actually the chemical reactions of the ethanolysis or esterolysis of mono-acyl-glycerols, which is highly selective and efficient methods of biofuel production.

Another innovation is the proposed method of adjusting the unfavorable temperature conditions in onestage technologies (less than $80^{\circ} \mathrm{C}$ ) using inert solvents such as diphenyl oxide (DFO) or diphenylmethane (DFM). Due to the rather favorable functional properties of DFO and DFM, in particular: $\mathrm{t}_{\text {boiling }}>200^{\circ} \mathrm{C}, \mathrm{t}_{\text {freezing }} \approx$ $26-28{ }^{\circ} \mathrm{C}$, good solubility in oils, esters, alcohols, bioand mineral fuels, benzene, temperature conditions of both stages can be carried at a temperature range within $130-160{ }^{\circ} \mathrm{C}$. Moreover, the use of DFO or DFM in twostage technology provides not only the optimal temperature, but also the homogeneity of the reaction media, in particular at the stage of glycerolysis, as well as the simplicity of the operation of regeneration of the used solvents.

\subsection{Chemical-technological bases of two-stage} processes of ethanolysis and esterolysis

Common to both processes is the stage of glycerolysis of rapeseed oil in an inert heat-transfer solvent diphenylmethane (DFM) to transform tri-acylglycerol molecules of rapeseed oil into mono-acylglycerol, which are well soluble in bio- and mineral fuels. Glycerolysis is carried out using alkaline catalysis at a temperature of $160^{\circ} \mathrm{C}$, it can be described by the following equation:

$$
\begin{array}{r}
{[\mathrm{RC}(\mathrm{O})-]_{3}-\mathrm{O}_{3} \mathrm{C}_{3} \mathrm{H}_{5}+2 \mathrm{C}_{3} \mathrm{H}_{5}(\mathrm{OH})_{3} \leftrightarrow} \\
\leftrightarrow 3 \mathrm{RC}(\mathrm{O})-\mathrm{OCH}_{2}-\mathrm{C}_{2} \mathrm{H}_{3}(\mathrm{OH})_{2}
\end{array}
$$

The calculated amounts of all reagents are placed in $0.700 \mathrm{~kg}$ of heat-transfer solvent DFM or DFO heated to $50{ }^{\circ} \mathrm{C}$ : $0.893 \mathrm{~kg}$ of rapeseed oil, $0.1831(0.230 \mathrm{~kg})$ of glycerol, $0.017 \mathrm{~g}$ ( $1.5 \%$ by weight $)$ of $\mathrm{C}_{2} \mathrm{H}_{5} \mathrm{ONa}$ catalyst. Heat the homogeneous reaction mass with constant stirring for 4 hours at a temperature of $160{ }^{\circ} \mathrm{C}$. Under such conditions, $90-95 \%$ level of raw material conversion and $90-95 \%$ yield of mono-acyl-glycerols are achieved, that is $\approx 0.050-0.058 \mathrm{~kg}$ of rapeseed oil and $0.015-0.0181$ of glycerol remain in the product mass.

The next stage of the two-stage process is ethanolysis or esterolysis of mono-acyl-glycerols in an inert heat-transfer solvent DFM (boiling point $>200{ }^{\circ} \mathrm{C}$ ) to obtain ethyl esters of higher fatty acids $\mathrm{R}-\mathrm{C}(\mathrm{O})-\mathrm{O}-\mathrm{C}_{2} \mathrm{H}_{5}$, which are biofuels. Technological features of the second stage processes are: usage of intermediate product mass, which contains an inert heattransfer solvent $(0.700 \mathrm{~kg}$ DFM $)$, immediately after glycerolysis, to provide a high temperature of reaction $\approx$ $160{ }^{\circ} \mathrm{C}$ with constant stirring the mass for 5 hours; the reaction masses stay homogeneous in the reactor during the process; calculations are based on the consumption of $0.893 \mathrm{~kg}$ of rapeseed oil or $1.000 \mathrm{~kg}$ of mono-acyl glycerols and $25 \%$ excess of non-oil raw materials (ethanol or ethyl acetate) and 1,5\% of the corresponding catalyst; high selectivity of both methods relative to the main product - biofuels, 90 - $95 \%$ level of conversion of raw materials, 90 - $95 \%$ yield of biofuels of high quality are achived; the product masses of each methods contains only one water-soluble compound, respectively glycerol or monoacetin.

Material calculations are based on the consumption of the corresponding non-oil raw materials under the condition of $92 \%$ conversion and $25 \%$ excess

Separation of final products to release biofuels consists of the following stages: distillation of etanol or ethyl acetate; cooling of food masses to $8-10^{\circ} \mathrm{C}$ for 5 hours and filtering the crystallized solvent; washing the residual mass with water at $30^{\circ} \mathrm{C}$ to remove glycerol or monoacetin; distillation of biofuel under vacuum; the residue is a mixture of unreacted rapeseed oil and monoacyl glycerols.

Thus, both innovative methods of production of biofuels from rapeseed oil are similar in the main favorable factors, in particular: the direction of transesterification reactions, the homogeneity of the 
media in the solvent, high temperatures, and so on. That is why the technical and economic evaluation of both methods can be estimated using material balance of one of them, for example, the ethanolysis of rapeseed oil (Table 5).
Analysis of the material balance data of two-stage eganolysis of rapeseed oil (Table 5) shows that the technology of oil processing in heat-transfer solven is more effective than one-stage technologies because of a number of favorable factors namely: homogeneuous

Table 5

Material balance of biofuel production using a new two-stage method of ethanolysis of rapeseed oil in a heat-transfer solvent medium

\begin{tabular}{|c|c|c|c|c|c|c|c|}
\hline Raw materials & $\begin{array}{c}\text { Mass, } \\
\text { кg }\end{array}$ & $\begin{array}{c}\text { Volume, } \\
1\end{array}$ & $\begin{array}{c}\text { The } \\
\text { amount of } \\
\text { substance, } \\
\text { mol }\end{array}$ & Products & $\begin{array}{l}\text { Mass, } \\
\text { кg }\end{array}$ & $\begin{array}{c}\text { The } \\
\text { amount of } \\
\text { substance, } \\
\text { mol }\end{array}$ & $\begin{array}{c}\text { Yield, Y } \\
\text { Contents, } \\
\text { C, } \%\end{array}$ \\
\hline \multicolumn{8}{|c|}{ 1. The stage of glycerolysys } \\
\hline $\begin{array}{l}\text { Rapeseed oil } \\
\text { Glycerol: } \\
\text { under chemical } \\
\text { equation } \\
\text { under } 25 \% \text { excess } \\
\text { Catalyst } \\
\mathrm{C}_{2} \mathrm{H}_{5} \mathrm{ONa}, 1,5 \% \\
\text { of reaction mass } \\
\text { heat-transfer solvent } \\
\left(\mathrm{C}_{6} \mathrm{H}_{5}\right)_{2} \mathrm{CH}_{2}-Д Ф \mathrm{M}\end{array}$ & $\begin{array}{c}0,893 \\
0,184 \\
230 \\
0,017 \\
0,700\end{array}$ & $\begin{array}{c}0,976 \\
0,146 \\
0,183 \\
-\end{array}$ & $\begin{array}{c}1,01 \\
2,00 \\
2,5 \\
0,25 \\
-\end{array}$ & $\begin{array}{l}\text { Main product } \\
\text { mono-acyl- } \\
\text { glycerols: } \\
\text { theoretical } \\
\text { actual } \\
\text { Excess of raw } \\
\text { materials: } \\
\text { glycerol } \\
\text { rapeseed oil } \\
\text { Catalyst } \\
\text { heat-transfer } \\
\text { solvent }\end{array}$ & $\begin{array}{l}0,046 \\
0,063 \\
0,017 \\
0,700\end{array}$ & $\begin{array}{c}0,50 \\
0,07 \\
0,25 \\
-\end{array}$ & $\begin{array}{c}\text { C-7\% } \\
\text { C-7\% } \\
- \\
-\end{array}$ \\
\hline Total & 1,840 & 1,129 & 3,76 & Total & 1,830 & 3,05 & \\
\hline \multicolumn{8}{|c|}{ 2.The stage of mono-acyl-glycerol ethanolysis } \\
\hline $\begin{array}{l}\text { mono-acyl-glycerols } \\
\text { ethanol: } \\
\text { under chemical } \\
\text { equation } \\
\text { under } 25 \% \text { excess } \\
\text { Catalyst } \\
\mathrm{C}_{2} \mathrm{H}_{5} \mathrm{ONa}, 1,5 \% \\
\text { of reaction mass } \\
\text { heat-transfer solvent } \\
\left(\mathrm{C}_{6} \mathrm{H}_{5}\right)_{2} \mathrm{CH}_{2}-Д Ф M\end{array}$ & $\begin{array}{l}1,000 \\
0,138 \\
0,173 \\
0,006 \\
0,700\end{array}$ & $\begin{array}{c}1,058 \\
0,174 \\
0,219 \\
- \\
-\end{array}$ & $\begin{array}{c}2,80 \\
\\
3,00 \\
3,76 \\
0,09 \\
- \\
-\end{array}$ & $\begin{array}{l}\text { Main product } \\
\text { biofuels: } \\
\text { By-products: } \\
\text { glycerol } \\
\text { raw materials: } \\
\text { ethanol } \\
\text { rapeseed oil } \\
\text { mono-acyl- } \\
\text { glycerols } \\
\text { heat-transfer } \\
\text { solven }\end{array}$ & $\begin{array}{c}0,085 \\
0,046 \\
0,063 \\
0,070 \\
0,700\end{array}$ & $\begin{array}{l}2,78 \\
0,93 \\
\\
1,00 \\
0,07 \\
0,23\end{array}$ & $\begin{array}{c}\text { B-93\% } \\
\text { BM- } \\
7,0 \% \\
- \\
- \\
- \\
-\end{array}$ \\
\hline Total & 1,179 & 1,277 & 6,65 & Total & 1,126 & 5,0 & \\
\hline
\end{tabular}

Table 6

Systematization of rapeseed oil transesterification methods and features of their technologies

\begin{tabular}{|c|c|c|c|}
\hline \multicolumn{2}{|c|}{$\begin{array}{l}\text { Alcoholysis is catalytic (alkali) transesterification of } \\
\text { vegetable oil molecules with alcohols: } \\
\text {-water-soluble methanol or ethanol, boiling point }<80^{\circ} \\
\mathrm{C} \text {; } \\
\text {-hardly water-soluble butanols or amyl alcohols, boiling } \\
\text { point }>110^{\circ} \mathrm{C}\end{array}$} & \multicolumn{2}{|c|}{$\begin{array}{l}\text { Esterolysis - catalytic (acidic) transesterification of oil } \\
\text { esters with acetates of alcohols: } \\
\text {-acetates of methyl or ethyl alcohols - methyl- or ethyl } \\
\text { acetates, boiling point }<86^{\circ} \mathrm{C} \text {; } \\
\text {-n-butyl-, isobutyl-, n-amyl-, isoamyl-, 2-ethyl-hexyl- } \\
\text { acetates, boiling point }>116^{\circ} \mathrm{C} \text {; }\end{array}$} \\
\hline \multicolumn{4}{|c|}{ The ways of technological processes implementation by appropriate methods } \\
\hline $\begin{array}{l}\text { One-stage method of } \\
\text { alcoholysis of } \\
\text { triacylglycerols of } \\
\text { vegetable oils to biofuels } \\
\text { or bioliquids }\end{array}$ & $\begin{array}{l}\text { Two-stage method using a } \\
\text { heat-transfer solvent } \\
\text { medium (DFO or DFM), } \\
t \sim 160^{\circ} \mathrm{C} \text { : } \\
\text {-glycerolysis of } \\
\text { triacylglycerol of } \\
\text { vegetable oils to } \\
\text { monoacylglycerols } \\
\text {-alcoholysis of } \\
\text { monoacylglycerols with } \\
\text { alcohols to biofuels }\end{array}$ & $\begin{array}{l}\text { One-stage method of } \\
\text { esterolysis of } \\
\text { triacylglycerols of } \\
\text { vegetable oils to biofuels } \\
\text { or bioliquids }\end{array}$ & $\begin{array}{l}\text { Two-stage method using a } \\
\text { heat-transfer solvent } \\
\text { medium (DFO or DFM), } \\
\mathrm{t} \sim 160^{\circ} \mathrm{C} \text { : } \\
\text {-glycerolysis of } \\
\text { triacylglycerol of } \\
\text { vegetable oils to } \\
\text { monoacylglycerols } \\
\text {-esterolysis of } \\
\text { monoacylglycerols with } \\
\text { alcohols to biofuels }\end{array}$ \\
\hline
\end{tabular}


Table 6

(continuation)

Features of obtained products:

Methanolysis -

ethanolysis of oils:

-heterogeneity

-significant excess of

alcohols

-limited heating $\left(70-80^{\circ} \mathrm{C}\right)$

-low selectivity for

biofuels and bioliquids,

low yield and quality of

biodiesel.

Glycerolysis of oils -
ethanolysis of
monoacylglycerols in
heat-transfer solvent
medium (DFO or DFM):
-homogeneity
- insignificant excess of
alcohols
-heating up to t $\sim 160^{\circ} \mathrm{C}$
-high selectivity for
biofuels and bioliquids,
low yield and quality of
biodiesel.

Esterolysis of oils with ethyl acetate:

-homogeneity

-high excess of ethyl

acetate

-limited heating $\left(70-80^{\circ} \mathrm{C}\right)$

-low selectivity for

biofuels and bioliquids,

low yield and quality of biodiesel.

Glycerolysis of vegetable oils - esterolysis of monoacylglycerols ethyl acetate in DFO or DFM: -homogeneity;

- insignificant excess of ethyl acetate

-heating up to $\mathrm{t} \sim 160^{\circ} \mathrm{C}$;

-high selectivity for biofuels and bioliquids, low yield and quality of biodiesel.

Physical, chemical and operational properties of diesel fuel, biodiesel and blended fuel

\begin{tabular}{|c|c|c|c|c|}
\hline \multirow{2}{*}{$\begin{array}{l}\text { Properties } \\
\text { (standarts) }\end{array}$} & \multirow{2}{*}{$\begin{array}{l}\text { Diesel, } \\
\text { DSTU } \\
3868-2005\end{array}$} & \multicolumn{2}{|c|}{$\begin{array}{c}\text { Biodiesel, DSTU 7178-2009, } \\
\text { EN } 14214\end{array}$} & \multirow{2}{*}{$\begin{array}{c}\text { Blended fuel } \\
\text { DSTU 6345-2014 }\end{array}$} \\
\hline & & $\begin{array}{l}\text { traditional one- } \\
\text { stage technology }\end{array}$ & $\begin{array}{c}\text { new two-stage } \\
\text { technology }\end{array}$ & \\
\hline $\begin{array}{l}\text { Density at } 20^{\circ} \mathrm{C}, \mathrm{kg} / \mathrm{m}^{3}(\mathrm{DSTU} \\
\text { ISO } 12185)\end{array}$ & $840-860$ & $880-890$ & $870-876$ & $860-865$ \\
\hline $\begin{array}{l}\text { Viscosity at } 20^{\circ} \mathrm{C}, \mathrm{mm}^{2} / \mathrm{s} \\
\text { (DSTU-GOST } 33 \text { ) }\end{array}$ & $3,0-6,0$ & $8,5-9,5$ & $7,0-7,5$ & $4,5-5,5$ \\
\hline $\begin{array}{l}\text { Cetane number }(\mathrm{CN}) \text {, more than } \\
\text { (DSTU ISO 5165) }\end{array}$ & 50 & 48 & 51 & 51 \\
\hline $\begin{array}{l}\text { Flash point, }{ }^{\circ} \mathrm{C}(\mathrm{DSTU} \text { ISO } \\
2719) \text { not less than } \\
\text { Cloud point, }{ }^{\circ} \mathrm{C} \text {, less than } \\
\text { Cold filter plugging point, }{ }^{\circ} \mathrm{C} \text {, } \\
\text { less than }\end{array}$ & $\begin{array}{l}65 \\
-10 \\
-5 \\
\end{array}$ & $\begin{array}{c}125-135 \\
-9 \\
-7 \\
\end{array}$ & $\begin{array}{l}110-115 \\
-7 \\
-10 \\
\end{array}$ & $\begin{array}{l}75-80 \\
-9 \\
-6 \\
\end{array}$ \\
\hline $\begin{array}{l}\text { Fractional composition, }{ }^{\circ} \mathrm{C} \text {, less } \\
\text { than } \\
-50 \% \text { об } \\
-90 \% \text { об }\end{array}$ & $\begin{array}{l}280 \\
340\end{array}$ & $\begin{array}{l}- \\
-\end{array}$ & - & $\begin{array}{c}260 \\
320\end{array}$ \\
\hline $\begin{array}{l}\text { Acid number (AN), mgKOH/g, } \\
\text { less than (DSTU 14104) }\end{array}$ & 0,03 & 0,65 & 0,50 & 0,12 \\
\hline $\begin{array}{l}\text { Iodine number (IN), } \mathrm{mgI}_{2} / 100 \mathrm{~g} \text {, } \\
\text { less than (DSTU EN 14111) }\end{array}$ & 5,0 & 125 & 120 & $15-25$ \\
\hline $\begin{array}{l}\text { Coking capacity of } 10 \% \text { of } \\
\text { distillation residue, } \% \text {, less than } \\
\text { (GOST 199932) }\end{array}$ & 0,3 & 0,45 & 0,35 & 0,32 \\
\hline Sulfur content, $\%$, less than & 0,01 & - & - & 0,009 \\
\hline $\begin{array}{l}\text { Corrosion, test on the } \mathrm{Cu}^{0} \text { plate } \\
\text { at } 50^{\circ} \mathrm{C}, 3 \text { hours (GOST 6321) }\end{array}$ & $\begin{array}{l}\text { Stand, } \\
\text { class } 1\end{array}$ & Does not stand & Does not stand & $\begin{array}{l}\text { Stand, } \\
\text { class }\end{array}$ \\
\hline $\begin{array}{l}\text { Mass fraction of glycerides and } \\
\text { glycerol, \%, less than (DSTU } \\
\text { EN 14105) }\end{array}$ & - & 3,50 & 0,35 & 0,30 \\
\hline $\begin{array}{l}\text { The fuel composition, } \\
\text { ratio of } \mathrm{C}: \mathrm{H}\end{array}$ & 6,9 & 6,7 & 6,4 & 6,7 \\
\hline $\begin{array}{l}\text { Air consumption, } \\
\text { air } \mathrm{kg} / \text { fuel } \mathrm{kg}\end{array}$ & $12,5-12,7$ & $14,2-14,5$ & $13,5-14,2$ & $13,0-13,3$ \\
\hline Low heat value, $\mathrm{MJ} / \mathrm{kg}$ & 43 & 33 & 35 & 41 \\
\hline $\begin{array}{l}\text { Biodegradability, test CEC-L- } \\
33 \mathrm{~A}-94, \%\end{array}$ & 25 & 85 & 85 & 45 \\
\hline $\begin{array}{l}\text { Antifriction properties, diameter } \\
\text { of wear spots, mm (the friction } \\
\text { mashine, GOST 9490-75) }\end{array}$ & 0,45 & 0,65 & 0,50 & 0,45 \\
\hline
\end{tabular}


media at optimized temperature $\left(150-160{ }^{\circ} \mathrm{C}\right)$, high levels of selectivity, high yield and quality of biodiesel.

Table 7 shows the main properties of biofuels obtained in different ways, as well as blended fuel, which is a mixture of diesel fuel containing $20 \%$ biofuel and $80 \%$ of mineral diesel fuel $[9,10,11,12]$.

Comparison of the properties of the two types of biofuels (Table 7) shows that the fuel obtained by the two-stage technology has better properties than the fuel obtained by the one-stage technology. In accordance with the requirements of DSTU 7178-2009 fuel obtained by the two-stage technology has lower glyceride content, viscosity, acid and iodine number etc. Ehe data in Table 7 confirm the advantages of the two-stage method of ethanolysis in a heat-transfer solvent medium. Such advantages relate to a number of technologically favorable factors, namely, homogeneous reaction medium, high selectivity of chemical reactions of both stages, high process temperature, state of chemical equilibrium $[4,8,9,10,13]$.

\section{Conclusions}

It is confirmed that traditional technologies of biofuel production are low-selective corresponding to biofuels and bioliquids, low yield of biofuels and their quality.

The method for the biofuel production by esterolysis of vegetable oils with alkyl acetates has been developed. It is shown that the technology of esterolysis solves the problem of excess alcohol content in biofuels. Alkyl acetates do not need to be removed from biofuels because they act as promoters of diesel fuel combustion.

An innovative method of two-stage alcoholysis and esterolysis is proposed. At the first stage rapeseed oil is modified by glycerolysis. The temperature conditions of the process is modified due to the use of heat-transfer solvent, which allows to increase the process temperature and causes high selectivity of the chemical reactions, biofuel yield and quality.

Kyrychenko V.I. - professor, Dr of Sc;

Kyrychenko V.V. - specialist;

Ribun V.S. - lead engineer of Chemistry Department;

Skladaniuk M.B.- PhD, assistant professor of Chemistry Department.

[1] V.I. Kyrychenko, G.O. Sirenko, S.V. Boichenko, Modern fuels and lubricants: state and progress of development (Private publishing house Suprun V.P., Ivano-Frankivsk, 2017).

[2] G.O. Sirenko, V.I. Kyrychenko, I.V. Sulyma, Physics and chemistry of fuels and lubricants (Private publishing house Suprun V.P., Ivano-Frankivsk, 2017).

[3] S.P. Singh, D. Singh, Renewable and Sustainable Energy Reviews 14, 200 (2010) (http://doi.org/10.1016/j.rser.2009.07.017).

[4] L. Labeski, A. Cairns, J. Xia, F. Megaritis, H. Hao, L. Canippa, Applied Energy 95, 139 (2012) (http://doi.org/10.1016/j.sciaf.2020.e00290).

[5] V. Zlatar, M. Abramovich, Journal of the American Oil Chemists'Society 95(1), 1431 (2018) (http://doi.org/10.1002/aocs.12133).

[6] N.G. Sialis, A.C. Kimbaris, C.S. Pappas, H.A. Tarantilis, M.G. Polission, Journal of the American Oil Chemisls'Socicty 1, 53 (2008) (http://doi.org/10.1007/s11746-006-1175-1).

[7] Z. Wciyand, K. Sanur, G.B. David, Journal of the American Oil Chemists'Society 4, 367 (2003) (http://doi.org/10.1007/s11746-003-0705-1).

[8] R. El-Araby, A. Amin, A. El-Morsi, N. El-Ibiari, G. El-Diwani, Egyptian Journal of Petroleum 27, 187 (2018) (http://doi.org/10.1016/j.ejpe.2017.03.002).

[9] S. Pinzi, P. Rounce, J.M. Herreros, A. Tsolakis, M.P. Dordo, Fuel 104, 170 (2013) (http://doi.org/10.1016/j.fuel.2012.08.056).

[10] X. Wang, Y. Ge, X. Feng, L. Yu, Fuel 107, 852 (2013) (http://doi.org/10.1016/j.fuel.2013.01.060).

[11] P.S. Wang, M.E. Tat, J. Van Gerpen, Journal of the American Oil Chemists'Society 11, 845 (2005) (http://doi.org/10.1007/s11746-005-1153-7).

[12] S.V. Boichenko, Motor fuels. Properties and quality (Publishing House of the National Aviation University, Kyiv, 2017).

[13] V. Ribun, S. Kurta, T. Hromovy, O. Khatsevich, Physics and chemistry of solid state 19(3), 258 (2017) (http://doi.org/10.15330/pcss.19.3.258-269). 


\title{
В.І. Кириченко ${ }^{1}$, В.В. Кириченко ${ }^{2}$, В.С. Рібун ${ }^{3}$, М.Б. Складанюк ${ }^{3}$
}

\section{Альтернативні палива із технічних олій: інноваційні методи і технології одержання та використання}

\author{
${ }^{1}$ ДВНЗ «Хмельницький начіональний університет», м. Хмельницюкий, Украйна, vikirich@ukr.net \\ ${ }^{2}$ TOB «Пейселл», м. Київ, Україна, Kyrychenkovk@gmail.com \\ ${ }^{3}$ ДВНЗ «Прикарпатський національний університет імені Василя Стефаника», м. Івано-Франківськ, Украйна,
} ribun.vika@gmail.com, skladanyuk16@gmail.com

Традиційні способи виготовлення біопалива з рослинних олій та аліфатичних спиртів (алкоголіз) мають ряд недоліків. В даній роботі запропоновано новий метод переестерифікації рослинних олій алкіл ацетатами (естероліз). Естероліз усуває проблему вмісту спиртів у біопаливі. Алкілацетати не потрібно виділяти 3 біопалива, оскільки вони виконують роль промоторів згоряння дизельного палива. Запропоновано спосіб удосконалення технологій алкоголізу та естеролізу шляхом модифікації температурного режиму. Розроблено хіміко-технологічні основи двостадійного процесу переестерифікації рослинних олій. На першій стадії здійснюють алкоголіз олій гліцерином (гліцероліз) 3 метою перетворення три-ацил-гліцеролів олій на моно-ацил-гліцероли. На другій стадії проводять алкоголіз етанолом (етаноліз) чи естероліз моно-ацил-гліцеролів. Оптимізовано температурний режим процесу переестерифікації шляхом використання розчинників-теплоносіїв. Порівняльний аналіз наведених матеріальних балансів технологій одно- і двостадійних способів етанолізу та естеролізу показав значне зростання селективності процесу, виходу і якості біопалива. Аналіз отриманих біопалив та ï 20 \% сумішей 3 дизельним паливом показав, що найбільш раціональним напрямком використання біопалива $є$ формування композиційних палив.

Ключові слова: ріпакова олія, етаноліз, естероліз, три-ацил-гліцероли, моно-ацил-гліцероли, біопаливо, композиційне паливо. 